\title{
TOPICALITY OF CRAFTS IN THE DEVELOPMENT OF JELGAVA OLD TOWN QUARTER
}

Liga Jankova ${ }^{1}$, assistant professor, Dr.oec.; Andrejs Lazdins ${ }^{2}$, assistant professor, Dr.oec.; Madara Dobele ${ }^{3}$, lecturer, Mg.oec.; Aina Dobele ${ }^{4}$, professor, Dr.oec. 1,2,3,4 Latvia University of Life Sciences and Technologies

\begin{abstract}
The development of small towns in Latvia is strongly affected by the growth of the tourism industry. New tourism products and sightseeing objects are created to develop local tourism and increase the number of visitors to cities/regions owing to municipal support. It has been found that in artisanal quarters, product sales and educational masterclasses create a new added value for tourism, thereby contributing to the sustainable development of the area. The first part of the research explained the role of crafts and artisans in urban development. The second part of the research performed a comparison of the operational patterns of current houses and centres of crafts, conducted an expert survey of administrators of the houses and centres of crafts and identified the demand for artisan products by the population and their interests in the development of the Jelgava Old Town street quarter. The research has concluded that in order for crafts to survive, national and local government support is needed for creating houses, centres, quarters and streets of crafts, improving the infrastructure for artisans to work and for tourists to visit them. Municipalities need to develop and implement a policy and a programme for craft development. Crafts have transformed into the cultural industry and in many autonomous communities, the craft competences have merged with tourism and contributed to a broad supply of products and have become important for the development of the area. Overall, the number of visitors to some Jelgava city tourism facilities increased in 2018 , yet the total number of visitors decreased. This indicates that the city needs new local tourism facilities. Four operational patterns of houses and centres of crafts were identified in Latvia. Crafts as an important and supportive activity to be developed are incorporated in a number of European, national, Zemgale planning region, Jelgava city and region development strategies and programmes, thereby emphasizing the support needed for traditional artisan activities. Respondents highly rated the need for a house of crafts in the Jelgava Old Town street quarter - $45 \%$ expressed very convincing opinions, while $42 \%$ rated it as average. The main benefits in the context of craft functions pertain to the cultural and historical heritage and social value. Further research studies are needed to analyse the economic and creative/innovative functions of crafts.
\end{abstract}

Keywords: crafts, artisan, functions.

JEL code: R110

\section{Introduction}

The development of small towns in Latvia is largely based on the supply of tourism services. Jelgava is the fourth largest city in Latvia with a population of 61 thou. inhabitants and an area of $60 \mathrm{~km}^{2}$ and is located $40 \mathrm{~km}$ from the capital city of Riga. Jelgava city has a long and rich history, and its tourists are offered modern solutions to getting familiarised with historical stories as well as active recreation in the calm waters of Zemgale. The following local tourist attractions are available in Jelgava city - the Holy Trinity Church Tower, the Jelgava Palace Museum, the Jelgava History and Art Museum named after G. Eliass, the Family Vaul of the Dukes of Courland, the Adolfs Alunans Memorial Museum, the Jelgava Exhibition of the Latvian Railway History Museum, the Historical Vehicles Museum of Anru Motors Ltd, the Jelgava Firefighting Museum, the Mental Health Care History Museum of the Gintermuiza Hospital, the Palaces of Jelgava and Valdeka, the Manor House Villa Medem, churches of various denominations, historical monuments and sightseeing places, cultural sites, companies and farms open to visitors, nature and parks. Jelgava city has a well-landscaped Post Island, and a variety of events are organized there throughout the year, attracting local and foreign tourists, e.g. the annual International Ice and Sand Sculpture Festivals, the annual Latvian Milk, Honey and Bread Festival, the Seedling Days etc. According to data of Jelgava Regional Tourist 
Information Centre, 106.3 thou. tourists visited Jelgava city in 2018, which was $6 \%$ fewer than in 2017 and $8 \%$ fewer than in 2016. The most visited tourist attractions in Jelgava city in 2018 were as follows: the Holy Trinity Church Tower with 35 thou. visitors, the Caramel Workshop with 29 thou. visitors and the Jelgava History and Art Museum with 21 thou. visitors. Overall, the number of visitors to some Jelgava city facilities increased in 2018, whereas the total number of visitors to Jelgava decreased (Jelgava municipality, 2019). This indicates that Jelgava city needs new tourist attractions. Jelgava city was severely damaged during the Second World War, yet one historic quarter with $19^{\text {th }}$ century wooden buildings and street pavement has survived the war. To increase the number of tourists and extend the length of tourist stays in Jelgava, it is planned to restore historical wooden buildings in the historical part of Jelgava Old Town, thereby creating new tourist attractions: the Restoration Centre at 14 Old Town Street and the House of Crafts in K.Barons Street. The municipality develops this tourism attraction through European Regional Development Fund project No.5.5.1.0/17/I/002 Preservation and Development of a Significant Cultural and Historical Heritage for Improving the Supply of Cultural Tourism in Zemgale Region. The total cost of the project is EUR $7.1 \mathrm{mln}$., incl. ERDF funding of EUR $2.4 \mathrm{mln}$. and municipal funding of EUR $4.5 \mathrm{mln}$. The Jelgava Old Town House of Crafts plans to concentrate various kinds of artisans in one place; the artisans would be closer to the flow of tourism in the city, and new tourism products would be created in the city. The demand for artisan products as a component of local tourism products has been little researched in Latvia. The authors did a theoretical and empirical examination of the role of the house of crafts and artisan services in urban development. The aim of the research is to identify the role of market demand for artisan services in the development of the Jelgava Old Town House of Crafts. Research tasks: 1 ) to identify and analyse theoretical findings and legal documents on the role of demand for crafts and artisans in urban development; 2 ) to identify the developments in and specifics of crafts by means of an expert and population survey and analyse the qualitative and quantitative indicators of the market demand. The research object is the development of Jelgava Old Town. The research subject is the need for the House of Crafts in Jelgava Old Town. The novelty of the research lies in the uniqueness of the data collected and analysed, as to date no information on the role of the Jelgava Old Town House of Crafts has been collected and analysed. Research methods: content analysis of theoretical and Internet sources, the abstract method, qualitative and quantitative analysis, data processing and interpretation by means of statistical analysis methods: data grouping, comparison and calculation of factors. The analysis period: 2019. Data sources: Jelgava City Council, Jelgava Regional Tourist Information Centre, a survey of residents of Jelgava city and Jelgava municipality as well as other areas of Latvia and a survey of administrators of 10 houses and centres of crafts in Latvia. The research question is as follows: does Jelgava Old Town need a house of crafts?

\section{Research results and discussion}

To understand a house of crafts as a component of local tourism, the following terms were theoretically examined: artisan, crafts, craft items and craft functions.

Artisan:

- in accordance with the Handicrafts Law (1993), individuals and legal entities have the right to the title "artisan" or "craft master";

- in Latvia, the profession of artisan is listed in the National Classification of Occupations (LM, 2017); 
- Latvia has developed a system specifying the way how to become an artisan, qualifying for various levels of craftsmanship (Jankova, Lazdins, Auzina, 2018).

Crafts:

- represent the professional activity of individuals in occupations, the list of which is approved by the Cabinet; some restrictions are imposed on acquiring the title "artisan" or "craft master" (Handicrafts Law, 1993);

- legal documents define a craft enterprise as an economic operator engaged in crafts. Latvia has developed a system specifying the way how to become an artisan, qualifying for various levels of craftsmanship (Jankova, Lazdins, Auzina, 2018);

- crafts represent diverse meanings and perspectives. According to the public good approach, artisans create things with a certain "value added" (Development, 2014);

- crafts represent a production industry capable of developing by using local inputs, thereby contributing to the development of national specificities both in terms of culture and production. A production method that maximizes the exploitation of local resources and serves for selling unique products that have evolved and retained a set of physical, economic, social capabilities under the guidance of a single specialist (LAK, 2019).

\section{Craft items:}

- represent national technical knowledge and aesthetic prerequisites that reflect the product's association with the essential characteristics of its community. They give testimonies of secular knowledge passed on through generations, whereby some objects whose dimensions, materials, techniques and ornaments are still being developed represent a particular nation's world view (Nilsson, 2019);

- are recognized as unique in the national and international markets. They contribute to the visibility of Latvia and demonstrate the national identity. To produce contemporary craft products, artisans employ state-of-the-art technologies and materials; the products are different from massproduced, unique, of high quality and individualistic (Development, 2014).

In many countries around the world, crafts are supported by governmental cultural and tourism policies, and significant investments are made in urban or other areas to operate centres, houses, streets and whole quarters of crafts and arts. Municipalities construct the infrastructure for artisans to operate (F. Ammar (2017) (Tunisia), F. Baez, L. Collin (1981) (Mexico), M. Bilgin, E. Demir, M. Lau, C. Kin-Man, Z. Zhang (2011) (Turkey), J. Divandari, A. Danaeinia, P. Izadi (2017) (India). As regards craft functions, the authors combined the theoretical characteristics of crafts (Table 1), which express the diverse functions of crafts. Each function adds a new value to the craft, creating a value chain (Guffog, 2016).

The importance of crafts at the European Union level was emphasized already in 2016. The project (ERDF) Central Baltic Crafts has found that there are artisans who would like to use their skills, yet they lack opportunities to develop the skills to meet the needs of buyers and sell their products effectively. Besides, most craft items are sold at fairs or souvenir shops and only during summer the tourism season. To provide support for artisans and provide them with a place where to work, teach, learn, share experience and hold seminars and exhibitions, they need the infrastructure that the artisans themselves cannot afford (Europe, 2016). Crafts as an important and supportive occupation to be developed are incorporated in a number of national laws and regulations, as well as in the strategies and programmes of the planning regions, cities and municipalities of Latvia. An 
analysis of various national legal documents - the Handicrafts Law (1993), Cabinet regulation No. 762 Regulation regarding Occupations in which the Professional Activity of a Person is Considered to be Crafts (2009), the Intangible Cultural Heritage Law (2016), the UNESCO International Multilateral Convention for the Safeguarding of the Intangible Cultural Heritage (2006) - stress that traditional artisans need support from the national and municipal governments to build necessary infrastructures. EU-funded projects implemented in the period 2012-2027 also play an important role.

\section{Functions and characteristics of crafts}

\begin{tabular}{|c|c|c|c|}
\hline No. & Functions & Value & Authors \\
\hline 1. & $\begin{array}{l}\text { Cultural, } \\
\text { historical and } \\
\text { educational }\end{array}$ & $\begin{array}{l}\text { Ancient skills and cultural heritage are preserved through } \\
\text { developing products/services; ancient skills are a symbol of } \\
\text { national identity traditions; societal cultural identity } \\
\text { competences are built up and passed on to future } \\
\text { generations. }\end{array}$ & $\begin{array}{l}\text { Nilsson, 2019, } \\
\text { Barbora, } 2017\end{array}$ \\
\hline 2. & $\begin{array}{l}\text { Innovative and } \\
\text { creative }\end{array}$ & $\begin{array}{l}\text { High value-added products/services are virtually and } \\
\text { intelligently created and sold by creative industries. New } \\
\text { craft products in terms of design are developed by using } \\
\text { modern technologies. Latvian identity, cultural heritage, } \\
\text { ethnographic signs and "sources" of natural wealth give } \\
\text { inspiration and information while taking care of preserving, } \\
\text { developing and transferring ancient, traditional and long- } \\
\text { term skills and knowledge. }\end{array}$ & $\begin{array}{l}\text { Development, 2014, } \\
\text { Divandari, 2017, } \\
\text { Sandell, } 2016\end{array}$ \\
\hline 3. & $\begin{array}{l}\text { Economic and } \\
\text { social }\end{array}$ & $\begin{array}{l}\text { Crafts represent the kind of economic activity whereby } \\
\text { artisans sell their products or services and pay taxes; the } \\
\text { artisans belong to economic entities, and their enterprises } \\
\text { provide jobs, reduce social tension in the area and represent } \\
\text { creators of economic and social values. }\end{array}$ & $\begin{array}{l}\text { Divandari, 2017, } \\
\text { Ammar, 2017, } \\
\text { Hadgich, 2005, } \\
\text { Jeroscenkova et al., } \\
2015\end{array}$ \\
\hline 4. & $\begin{array}{l}\text { Regional and } \\
\text { urban } \\
\text { development }\end{array}$ & $\begin{array}{l}\text { A recognizable image of a locality - a city, a municipality or } \\
\text { a region - is created, the environment is used sustainably, } \\
\text { brownfields are regenerated, the environment for tourism is } \\
\text { transformed. Adjacent areas and services are developed, and } \\
\text { business activity is facilitated. A higher value-added could be } \\
\text { generated in the area. }\end{array}$ & Danosa, 2019 \\
\hline 5. & $\begin{array}{l}\text { Tourism and } \\
\text { marketing }\end{array}$ & $\begin{array}{l}\text { Tourist attractions - houses, centres, associations and } \\
\text { quarters of crafts - represent new tourism products and } \\
\text { marketing elements. Focus is placed on customer (buyer, } \\
\text { tourist etc.) needs. }\end{array}$ & $\begin{array}{l}\text { Lukich et al., 2015, } \\
\text { Dutton, } 1983\end{array}$ \\
\hline
\end{tabular}

Source: authors' compilation

The National Development Plan of Latvia for 2013-2020 (NDP, 2012) emphasizes unique cultural and creative human capital resources as factors of competitive non-agricultural entrepreneurship and identifies courses of action to support traditional artisans in developing products and services by employing tangible and intangible heritage. The responsible institutions are the Ministry of Agriculture (MoA), the Ministry of Culture (MoC), the Ministry of Education Science (MoES), local governments, social partners and non-governmental organizations (NDP, 2012). The Informative Report on the Interim Assessment of the Implementation of the Guidelines for Tourism Development in Latvia for 2014-2020 in the period 2014-2016 stresses the need for new tourism products with high added value for the competitiveness and quality of national tourism products (Informative, 2017).

The Sustainable Development Strategy of Zemgale Planning Region for 2015-2030 stresses that Zemgale planning region has long traditions of industrial production and crafts. The economic profile of Zemgale Planning Region encompasses four main specializations, one of which is tourism and crafts as a brand of regional identity (Zemgale, 2014). The strategic part of the Development Programme of Zemgale Planning Region for 2015-2020 (2015) states that workshops or houses of 
crafts as well as individual artisans operate in every municipality of Zemgale planning region. Crafts and home production are promising segments of the economy that should be consolidated in the future by developing a unified network of regional artisans and home producers, increasing the competitiveness of local products in various markets and expanding the supply of tourism products made in the region, specifically in the fields of crafts, home production and rural tourism. It is required to support the development of crafts, home production and the cultural and creative industries (Zemgale, 2015). An analysis of relevant legislative acts, as well as planning and policy documents allows concluding that all the documents analysed indicate that crafts as an occupation should be developed and promoted. The idea of developing the Jelgava Old Town street quarter is not in contradiction with the legal and policy documents. An analysis of national experience is required to understand the need for houses and centres of crafts in the region.

Houses and centres of crafts in Latvia. At present, there are $\mathbf{2 8 0}$ houses and centres of crafts in Latvia (Handcrafts of Latvia). An analysis of the information available on the websites of the houses and centres of crafts reveals that the geographical distribution of the houses and centres of crafts in the regions of Latvia are not homogenous (Figure 1). The houses and centres of crafts are mostly located in Latgale $(65 \%)$ and Vidzeme (19\%) planning regions, followed by Kurzeme ( $9 \%$ ) and Zemgale ( $7 \%$ ) planning regions. An analysis of the kinds of economic activity in which artisans are engaged reveals that the kinds are very diverse - various activities related to traditional culture, crafts, the Latvian way of life, household skills and culinary heritage are carried out by the artisans. They offer seasonal celebrations, family fun programmes - weddings, baptisms and trips with lectures and demonstrations. They also offer to master historical craft skills such as weaving, musical instrument making, ceramics, photography, paper making, woodworking, bread and flour product making, meat, fish processing, wine, cider and vodka making, knitting, crocheting, weaving, jewellery making, metal processing, confectionery and chocolate making etc. in workshops and master classes.

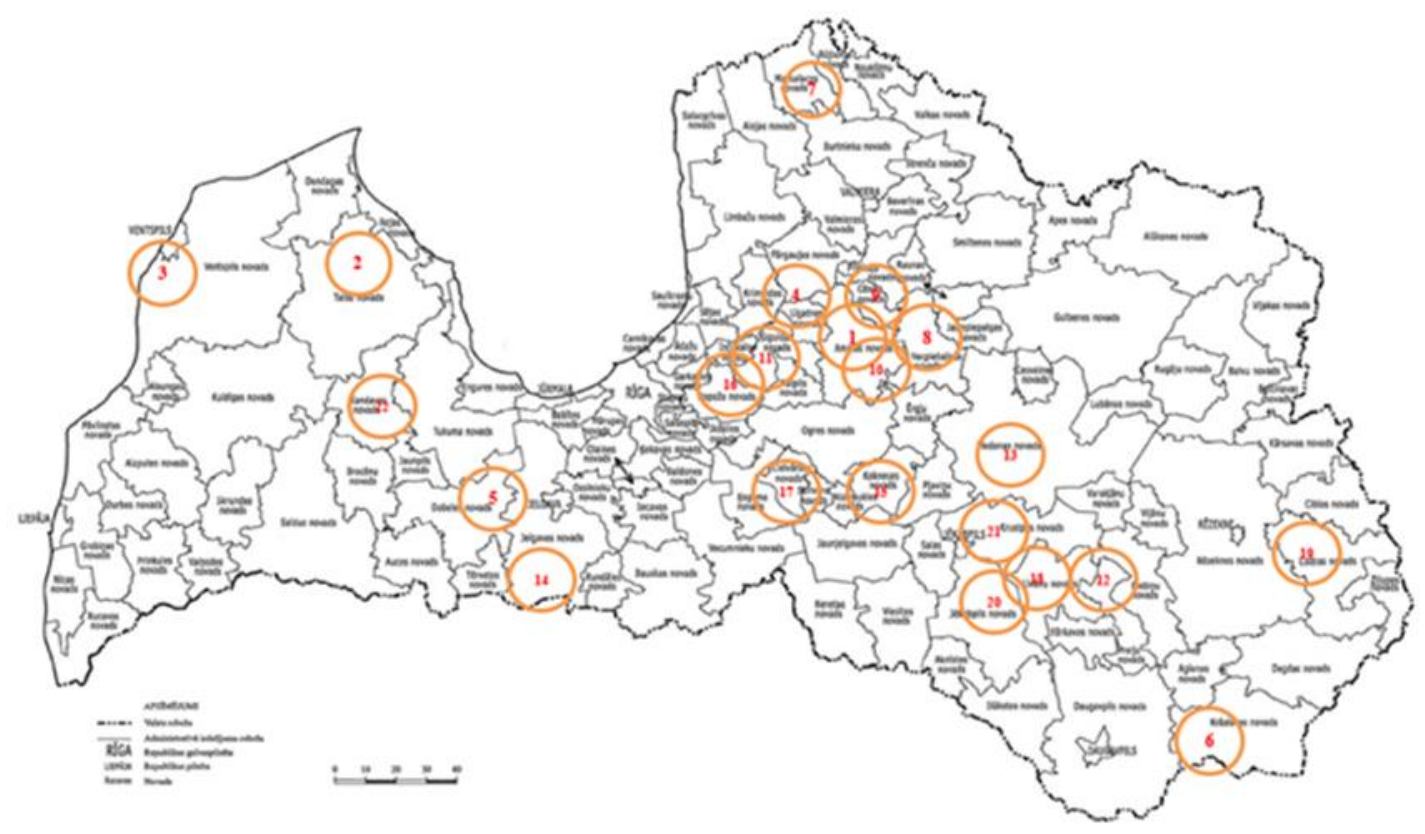

Source: authors' construction Handcrafts of Latvia

Fig. 1. Geographical distribution of houses of crafts in the municipalities of Latvia

There are five artisan centres in Jelgava municipality where everyone has an opportunity to master the skills of weaving, crocheting, beading, loom knitting etc. There is a pottery workshop, 
woodworking and leather processing workshops and a centre of applied arts. Jelgava city does not have its own craft centre.

An expert survey was conducted to identify the need for houses of crafts in Latvia. Ten experts from the planning regions of Latvia participated in the survey. Two experts from each of the planning regions who practically administrated homes or centres of crafts were randomly selected for the survey. Questions were asked by telephone, and they related to the operational patterns and financing of houses and centres of crafts, changes in the visitor flow, the practical application of the craft skills built up, production marketing, cooperation among artisans and craft functions. Summarizing the views and experience of the experts allows identifying four most common operational patterns for homes and centres of crafts:

1) homes and centres of crafts are established and maintained by municipalities in municipal premises. The cost of maintenance is covered from municipal budgets. The municipality hires employees. External funding from the EU and other funds is attracted for municipal development;

2) homes and centres of crafts are maintained by municipalities in municipal premises. The municipality rents premises out to artisans - legal entities: Ltds, foundations and associations. The municipality supports legal entities by lower rents and by hiring educators. Houses and centres of crafts are maintained from their own revenue. External funding from the EU and other funds is attracted for municipal development;

3) homes and centres of crafts are established and maintained by legal entities: Ltds, foundations and associations. Houses and centres of crafts are maintained from their own revenue. External funding from the EU and other funds is attracted for municipal development;

4) homes and centres of crafts are established and maintained by private persons who are economic operators and patent payers. The maintenance is provided by means of donations from visitors. External funding from the EU and other funds as well as support programmes for municipalities is attracted for municipal development.

According to the experts, the flow of visitors to the houses and centres of crafts has increased since 2013. Domestic and foreign tourists have become more interested in crafts. The skills built up at the houses and centres of crafts have contributed to expanding the product assortment of local entrepreneurs, and new tourism products have been designed as a result of operation of the houses and centres of crafts. Artisans were reluctant to cooperate with each other to market their products. Artisans used to sell their products during fairs and local and regional festivals as well as to tourist groups. The administrators believed that the homes and centres of crafts performed mostly the cultural, historical and educational functions of crafts in the sense of their diverse values. They did not deny that the value generation approach was applied to economic, social and territorial development. The homes and centres of crafts did not count their visitors and had difficulty in collecting data on the economic and social benefits they generated.

In September and October 2019, a survey was conducted to find out the opinions of inhabitants of Latvia, including Jelgava municipality and Jelgava city, on the need for a house of crafts in the Jelgava Old Town street quarter. The questionnaires could be filled in person or electronically. Totally, 193 respondents were surveyed, the respondents had to rate 16 assertions on a 10-point scale developed by Fishbein (1967), with 1 being the least important and 10 the most important. The assertions to be rated by respondents pertained to five groups of functions of crafts (Table 1). In addition, the respondents were requested to give their opinions on whether the creation and operation of a house of crafts in Jelgava require national and local government support, or whether 
the visitors of the quarter of crafts are ready to participate in paid classes delivered at the house of crafts. The survey data were processed using MS Excel. The total score was computed for the assertions of each function group. The results of the survey were processed using also a quantitative method for product consumption value determination. The computations were based on the methodology used to determine the consumption value of a product (Praude, Linina, 2018).

$$
P V_{i=\sum_{j}^{n}=i\left(a_{i j \times B_{i j}}\right)}
$$

where $\mathrm{PV}_{\mathrm{i}}$ - consumption value of the $\mathrm{i}$-th product; $\mathrm{n}$ - number of qualities of the function group rated; $a_{i j}$ - properties of the $i$-th product, $j$ - importance factor; $B_{i j}$ - properties of the $i$-th product rating in points.

A summary of the survey results is shown in Table 2. The importance factor for a craft function from the perspective of respondents was obtained by multiplying the ratings of the assertions of each function group $\left(a_{i j}\right)$. An analysis of the results revealed that three in ten respondents preferred craft functions such as cultural, historical and educational (0.3) and regional and urban development (0.3). Two in ten respondents strongly believed that the development of the Jelgava Old Town street quarter should be funded from the national and municipal budgets.

An analysis of the results for the assertions of each function group revealed that the respondents were not ready to participate in paid craft skills development, which indicated that a large part of the public expected the municipality to cover all expenses related to the services of the house of crafts from its budget. A comparison of the ratings of each craft function group (Bij) revealed that the respondent opinions on function groups 1 through 5 , as well as their importance perceived by the respondents were similar, whereas function group 6 was rated the lowest. The average consumption values (PVi) computed for the craft functions revealed the demand for various function groups; the respondents preferred the cultural, historical and education function (5.1) and the regional and urban development function (5.1), followed by the funding model (3.0), which means that the development and maintenance of the quarter of crafts has to be funded by the municipality.

Table 2

Functional values of crafts

\begin{tabular}{|l|l|c|c|c|}
\hline No. & Name of the craft function & $\begin{array}{c}\text { Weights of craft } \\
\text { functions from } \\
\text { respondent } \\
\text { perspective (aij) }\end{array}$ & $\begin{array}{c}\text { Ratings of craft } \\
\text { functions } \\
\mathbf{1 , 2 , 3 , 4 , 5 , 6 , \%} \\
\text { (Bij) }\end{array}$ & $\begin{array}{c}\text { Consumption } \\
\text { value of the craft } \\
\text { function (PVi) }\end{array}$ \\
\hline $\mathbf{1}$ & $\begin{array}{l}\text { Cultural, historical and } \\
\text { educational }\end{array}$ & 0.3 & 17 & 5.1 \\
\hline $\mathbf{2}$ & Innovative and creative & 0.1 & 18 & 1.8 \\
\hline $\mathbf{3}$ & Economic and social & 0.1 & 17 & 1.7 \\
\hline $\mathbf{4}$ & $\begin{array}{l}\text { Regional and urban } \\
\text { development }\end{array}$ & 0.3 & 17 & 5.1 \\
\hline $\mathbf{5}$ & Tourism and marketing & 0.1 & 17 & 3 \\
\hline $\mathbf{6}$ & $\begin{array}{l}\text { Funding model for the } \\
\text { quarter of crafts }\end{array}$ & 0.2 & 15 & 3 \\
\hline $\mathbf{7}$ & Total & $\mathbf{1}$ & $\mathbf{1 0 0}$ & \\
\hline
\end{tabular}

Source: authors' calculations

The respondents rated the innovative and creative function (1.8), the economic and social function (1.7) and the tourism and marketing function (1.7) twice as low. However, average ratings dominated, which were relatively biased. Further research is needed to continue exploring the public's perception that craft skills training should be provided through interest-related education 
and funded by the municipality. Once these skills are acquired within a family, the skills are expected to be passed on from generation to generation.

\section{Conclusions, proposals, recommendations}

1) Summarizing and analysing the theoretical findings on the topicality of the demand for crafts in urban areas, it can be concluded that crafts promote the socio-economic development of the territory.

2) Theoretical findings refer of crafts to the value generation approach to be applied to economic, social and territorial development. In many countries around the world, crafts are supported by governmental cultural and tourism policies, and significant investments are made in urban or other areas to operate centres, houses, streets and whole quarters of crafts and arts.

3) Summarizing and analysing normative documents on the topicality of demand for crafts and crafts in the development of Europe, Latvia and Jelgava, it can be concluded that crafts as an important, supportable and development able activity is embedded in a number of European, Latvian, Zemgale planning region, Jelgava city and county development strategies and programs emphasize the need for support for traditional craft activities.

4) The respondents highly rated the need for a house of crafts in the Jelgava Old Town street quarter; $45 \%$ expressed very convincing opinions, while $42 \%$ rated it as average. The main benefits in the context of craft functions are the cultural and historical heritage and social value.

5) The respondents (92\%) almost unanimously believed that the development and maintenance of the Jelgava Old Town House of Crafts have to be funded by the national and local governments.

6) Based on the data collected in the field of crafts, it is important for local governments to develop a policy for the management of centres of crafts in order to continue attracting financial support from the EU Funds.

7) The research found that a house of crafts is needed in the Jelgava Old Town street quarter, and the current 19 artisans of Zemgale region and five artisans of Jelgava municipality could be potential entities for the house of crafts.

\section{Bibliography}

1. Ammar, F. (2017). The Growth Factors of Tunisian Handicraft Small and Medium-sized Enterprises (Smes): towards an Integration. International Journal of Technology Management \& Sustainable Development. Vol. 16 Issue 3, pp. 229-248.

2. Baez, F., Collin, L. (1981). Artes Populares e Indigenismo. Mexico Indigena, 50. Retrieved: http://www.pasosonline.org/Publicados/13215/PS0213_8.pdf. Access:02.10.2019.

3. Barbora, P. (2017). Identity, Tradition, and Revitalization of American Indian Cultures. Retrieved: http://ezproxy.Ilu.Iv:2108/ehost/ebookviewer/ebook/ZTAwMHh3d19fMTU1NjIxN19fQU41?sid=d75bae3a3c48-43d8-a0fa-95c41f8e49cf@sessionmgr103\&vid=8\&format=EB\&rid=1. Access:02.10.2019.

4. Bilgin, M., Demir, E., Lau, M., Kin-Man To, C., Zhang, Z. (2011). The Turkish Handmade Carpet Industry: Analysis in Comparison with Select Asian Countries. Journal of the Textile Institute, 102 (6), pp 514-526.

5. Danosa, D. (2019). Pieredzejuma turisms - mazpilsetu veiksmes atslega (Experienced Tourism - the Key to Small-Town Success). Retrieved: https://ir.lv/2019/08/12/pieredzejuma-turisms-mazpilsetu-veiksmesatslega/. Access:02.10.2019.

6. Divandari, J., Danaeinia, A., Izadi, P. (2017). Analysis of the Role of Handicraft Production in Rural Sustainable Development: A Case of Sar Aqa Seyyed, Chaharmahal and Bakhtiari Province. Journal of History, Culture \& Art Research / Tarih Kultur ve Sanat Arastirmalari Dergisi. Special issue, Vol. 6 Issue 1, pp. 549-565.

7. Dutton, R. (1983). Handicrafts in Oman and Their Role in Rural Community Development. Geoforum, 14 (3), pp. 341-352.

8. Fishbein, M.(1967). Behavior Theory Approuchto The Relations in Attitude Measurement. Reading in Attitude Theory Measurement. New York:John Wolley.

9. Guffog, T. (2016). Building Effective Value Chains : Value and Its Management. London : Kogan Page. Retrieved: $48 \mathrm{e} 4125 \mathrm{f} 1 \mathrm{f} 17 \% 40 \mathrm{sdc}-\mathrm{v}-$ 
sessmgr01\&bquery=value+chain\&bdata=JmRiPWUwMDB4d3cmdHIwZT0xJnNIYXJjaE1vZGU9U3RhbmRhcmQ mc2I0ZT1laG9zdC1saXZI. Access:18.12.2019.

10. Hadgich, O. (2005). Kulturni turizam. (Cultural Tourism). Novi Sad: Univerzitet u Novom Sadu, Prirodnomatematički fakultet, Departman za geografiju, turizam i hotelijerstvo.

11. Handcrafts of Latvia. Retrieved: https://www.celotajs.Iv/lv/c/brand/agriheritage/detailed/crafts?0. Access: 15.01.2020.

12. Informative Report on The Interim Assessment of the Implementation of the Guidelines for the Development of Tourism in Latvia for the Period 2014-2020.) (2014). Retrieved: https://www.em.gov.Iv/files/turisms/EMZin_181217_TUR_pamn_novert.pdf. Access:18.12.2019.

13. Jankova, L., Lazdins, A., Auzina,A. (2018). Activity of Master Craftsmen in Latvia. Proceedings of the International scientific conference "Economic science for rural development", Jelgava, May 9-11, 2018 / Latvia University of Life Sciences and Technologies. Faculty of Economics and Social Development. Jelgava, 2018. Nr. 47 : Rural development and entrepreneurship. Production and co-operation in agriculture. pp. 108-114.

14. Jelgavas pilseetas pašvaldiiba (Jelgava Municipality) (2019). Retrieved: https://www.jelgava.Iv/lv/pasvaldiba/dokumenti/projekti/2020-gads/. Access:18.12.2019.

15. Jelgavas Regionalais tuurisma informaacijas centrs (Jelgava Regional Tourism Information Centre) (2019). Statistika (Statistic). Apskates objekti. Retrieved: https://www.jelgava.Iv/files/jrtc_statistika_2016.pdf. Access: 18.12.2019.

16. Jeroscenoka, L., Rivza, B, Kruzmetra, M., Melece, L., Spaks, A., Artsiusheuski, M. (2015).The VALUE OF CULTURAL HERITAGE: THE STATE IN BELARUS AND LATVIA. Proceedings of the 25th NJF Congress, Nordic View to Sustainable Rural Development. pp.481- 488.

17. Latvijas Amatniecibas kamera (Latvian Chamber of Crafts)(LAK) (2019). İSS APSKATS PAR LAK. Retrieved: http://www.lak.lv/pub/?id=97. Access: 18.12.2019.

18. Lukich, T., Stojanovich, T., Derchan, B.,Zhivkovich M., Zivkovich, J.(2015). The Geographical Aspects of Traditional Handicrafts in Serbia European Researcher. 2015, Vol. 100 Issue 11, p747-758. 12p. DOI: 10.13187/er.2015.100.747. Database: Academic Search Complete.

19. National Development Plan of Latvia for 2013-2020 (NDP, 2012). Retrieved: https://likumi.Iv/doc.php?id=253919. Access: 15.01.2020.

20. Nemateriaala Kultuuras mantojuma likums (Intangible Cultural Heritage Law) (2016). LR likums. Retrieved: https://likumi.lv/ta/id/285526-nemateriala-kulturas-mantojuma-likums. Access: 15.01.2020.

21. Nilsson, I., Reid, N. (2019). The Value of a Craft Brewery: On the Relationship Between Craft Breweries and Property Values. Detail Only Available Academic Journal, Growth \& Change. Jun2019, Vol. 50 Issue 2, pp. 689-704.

22. Noteikumi par amatiem, kuros personas profesionala darbiba ir uzskatama par amatniecibu (The Provisions of Posts Which Personal Professional Activity is Considered as Crafts). MK noteikumi (Regulations of Minister Cabinet) nr. 762 (14.07.2009.). Retrieved: https://likumi.lv/doc.php?id=194944. Access: 15.01.2020.

23. Par Amatniecibu (Handicrafts Law) (1993). LR likums. Retrieved: https://likumi.lv/doc.php?id=63052. Access: 15.01.2020.

24. Praude,V.,Linina, I. (2018). Paardosanas vadiiba (Sales Management). R:Turiiba, pp. 217-221.

25. Rekomendaaciju izstraade par amatnieciibas nozares aarzemju labaas prakses paarnemsanu Latvijaa (Development of Recommendations on the Transfer of Foreign Good Practices of the Crafts Sector in Latvia)(2014). Zemgales plaanošanas regions. Peetiijums finanseets INTERREG IVC programmas projekta „Regionaalaa sadarbiiba amatnieciibas attiistiibai" / Regional Cooperation for Crafts' Development" ietvaros. Pasūtījuma līgums Nr. 12/1-14.2/112, 21.11.2012.

26. Sandell, T., Skarveli, L. (2016). Mapping Exercise: How Could Creative Industries Foster Innovation in Tourism in the Northern Dimension Area? https://www.ndpculture.org/media/W1siZiIsIjIwMTcvMDIvMjAvMm9iNGR1N2Y4NF9Dcm9zc19jb3VudHJ5X3JI cG9ydC5wZGYiXV0/Cross-country\%20report.pdf?sha=0d0b01455ac1799e. Access: 18.12.2019.

27. UNESCO International Multilateral Convention for the Safeguarding of the Intangible Cultural Heritage (2006)Retrieved: https://likumi.Iv/ta/lv/starptautiskie-ligumi/id/1533. Access: 15.01.2020.

28. Zemgales plaanosanas regiona attiistiibas programma 2015-2020 (Development Programme of Zemgale Planning Region for 2015-2020) STRATËGSISKĀ DAĻA (2015). APSTIPRINĀTA ar 18.08.2015. ZPRP lēmumu Nr. 131 (protokols Nr. 27).

29. Zemgales plaanosanas regiona ilgtspeejiigas attiistiibas strateegija 2015-2030 (Zemgale Planning Region Sustainable Development Strategy 2015-2030) (2014). APSTIPRINATA ar 18.08.2015. ZPRP leemumu Nr. 130 (protokols Nr. 27). 